\title{
Volatile and persistent real exchange rates without the contrivance of sticky prices
}

Michael J. Moore

Queen's University Belfast, Northern Ireland

Maurice J. Roche

National University of Ireland, Maynooth, Republic of Ireland

The flexible-price two-country monetary model is extended to include a consumption externality with habit persistence. The model is simulated using the artificial economy methodology. It successfully explains (i) the high volatility of nominal and real exchange rates, (ii) the high correlation between real and nominal rates, and (iii) the persistence of real exchange rates. It offers a neo-classical explanation for the Meese-Rogoff exchange rate forecasting puzzle.

Keywords: Artificial Economy; Real and Nominal Exchange Rates; Habit Persistence

JEL classification: F3; F4;

Michael J. Moore can be contacted at m.moore@qub.ac.uk Maurice J. Roche can be contacted at maurice.roche@may.ie 
If is there is an issue in international economics on which there is no consensus, it is why nominal exchange rates are so volatile. It is not hard to see why. In standard macroeconomic models ${ }^{1}$, the (log of) nominal exchange rate depends on the difference between (the logs of) home and foreign money and is proportional to the difference between (the logs of) home and foreign income. To mimic the volatility of nominal exchange rates, either money or income has to display variability that they obviously do not possess ${ }^{2}$. This has led a number of writers to despair of macroeconomics altogether. The most celebrated example is Flood and Rose (1999) who argue that forex market microstructure has more to contribute to our understanding of exchange rates than macroeconomics ${ }^{3}$.

The apparently excessive volatility of nominal exchange rates is not an isolated puzzle in international economics. Real exchange rates exhibit similar volatility and to compound the mystery, real and nominal rates are closely correlated ${ }^{4}$. The traditional response to this twist is to invoke sticky prices, the most recent manifestation of which is the new open economy macroeconomics (for a survey, see Lane, 2001). Specifically, Chari, Kehoe and McGrattan (2001) show that with price stickiness for at least four quarters, very low levels of the intertemporal elasticity of substitution, and a high cross-country correlation in shocks to money growth, their international business cycle model produces simulated moments that broadly mimic the properties of real and nominal exchange rates. Using translog preferences, staggered contracts and pricing to market, Bergin and Feenstra (2001) also explain the same stylised facts. The problem with this is that not all economists are content with results that depend on the arbitrary assumption of pre-set prices.

In this paper we simulate a very simple model that assumes perfectly flexible prices, complete risk sharing, plausible levels of the intertemporal elasticity of substitution and little or no cross-country correlation in shocks to money growth. The results also match the stylized facts ${ }^{5}$. Our modelling strategy is to extend Campbell and Cochrane (1999) 
preferences to both a monetary and an international setting. With this specification there is an aggregate consumption externality (see for example Abel (1990) and Duesenberry (1949)) and utility is time-inseparable because of habit persistence. The utility function depends not only on the consumption of home and foreign goods but also on the surplus of consumption over an externally generated habit that is both volatile and persistent. This makes the marginal rate of substitution between home and foreign goods volatile enough to explain the variability in real exchange rates. The high volatility of nominal exchange rates follows since prices are pinned down by the modest volatility of the money stock. The high correlation between real and nominal exchange rates also follows since variations in both have their common source in the 'surplus consumption ratio'.

What of the persistence of real and nominal exchange rates? Chari, Kehoe and McGrattan (2001) argue "the persistence in the real exchange rate is essentially determined by persistence of consumption" and that habit persistence, while increasing persistence in consumption typically leads to less volatile consumption and, hence less volatile exchange rates. In our model this impediment to explaining persistence does not arise because utility also depends on the home and foreign surplus consumption ratios. These are exogenously driven by highly persistent stochastic processes.

The closest contribution to the spirit of this paper is Finn (1999) who also uses a flexible price model to address some of the same issues. In her model, money is endogenous but there is a second source of real innovations in the form of shocks to the marginal efficiency of investment. She successfully explains the high correlation between real and nominal exchange rates as well as the persistence in both variables: however she is silent on their volatilities. Another anomaly is what Obstfeld and Rogoff (2001) label "the exchange-rate disconnect puzzle”. Meese and Rogoff (1983) showed that the forecasts from standard macroeconomic exchange rate models produce higher root mean squared errors than the 
random walk model. In this paper we show that these results could be due to the fact that standard macroeconomic exchange rate models omit a key variable that is related to habit persistence.

The plan of the paper is as follows. First, the model is developed. In section 2, we discuss the data. The model is calibrated in the third section. The results are presented in section 4. Finally, we make some concluding remarks.

\section{The model}

The basic structure of the model is the well-known Lucas (1982) two-country, two-good, two-money representative agent story. In this model the real exchange rate is equated with the intratemporal marginal rate of substitution between domestic and foreign goods and can be written as

$$
R_{t}=\frac{\delta U / \delta C_{i t}^{2}}{\delta U / \delta C_{i t}^{1}} .
$$

Utility is $U, C_{i t}^{j}$ is the consumption of goods and services of country $j$ by the household of country $i$ at time $t$ and $R_{t}$ is the time $t$ relative price of foreign to home goods expressed in a common currency. This is, of course, the real exchange rate ${ }^{6}$ It can be written as $R_{t}=S_{t} P_{t}^{2} / P_{t}^{1}$, where $S_{t}$ is the nominal exchange rate and $P_{t}^{j}$ is the price of country $j$ goods in terms of country $j$ money

$$
S_{t}=\frac{\left(\delta U / \delta C_{i t}^{2}\right) / P_{t}^{2}}{\left(\delta U / \delta C_{i t}^{1}\right) / P_{t}^{1}},
$$

respectively. The exchange rate is measured as the home price of foreign currency at time t. It is obvious that persistent, volatile and highly correlated real and nominal exchange rates will primarily depend on the properties of the intratemporal marginal rate of substitution and not necessarily on the time series properties of consumption. 
We will take the following simple model to illustrate the effects of introducing the habit externality on the time series properties of real and nominal exchange rates. Households in both countries ${ }^{7}$ are assumed to maximize the discounted expected value of lifetime utility. We will consider two cases. The first is the standard case where utility depends on consumptions only. The second case assumes that households also have habits in domestic and foreign goods. The utility functions are given as

$$
\begin{aligned}
\sum_{t=0}^{\infty} \beta^{t} U\left(C_{i t}^{1}, C_{i t}^{2}\right) & =\sum_{t=0}^{\infty} \beta^{t}\left(\frac{\left(C_{i t}^{1}\right)^{(1-\gamma)}}{1-\gamma}+\frac{\left(C_{i t}^{2}\right)^{(1-\gamma)}}{1-\gamma}\right), \quad i=1,2, \\
\sum_{t=0}^{\infty} \beta^{t} U\left(C_{i t}^{1}-H_{i t}^{1}, C_{i t}^{2}-H_{i t}^{2}\right) & =\sum_{t=0}^{\infty} \beta^{t}\left(\frac{\left(C_{i t}^{1}-H_{i t}^{1}\right)^{(1-\gamma)}}{1-\gamma}+\frac{\left(C_{i t}^{2}-H_{i t}^{2}\right)^{(1-\gamma)}}{1-\gamma}\right), \quad i=1,2,
\end{aligned}
$$

where $\beta$ is the discount factor, $1 / \gamma$ is the intertemporal elasticity of substitution, and $H_{i t}^{j}$ is the subsistence consumption (or habit ${ }^{8}$ ) of goods and services of country $j$ by the household of country $i$. Note that, if $H_{i t}^{j}=0, \forall i, j$ in equation (4) collapses to equation (3), which represents standard addilog preferences with no habit. Habit persistence takes the form of an aggregate consumption externality i.e. 'Keeping Up with the Jones’s' effects along the lines of Duesenberry (1949) and Abel (1990). Recent work in the economics of happiness literature suggests that relative income is an important factor in individual's levels of satisfaction; see for example Oswald and Clarke (1996) and Oswald (1997).

We reparameterize the utility function in equation (4) in terms of $X_{i t}^{j}$, the surplus consumption ratio of goods and services of country $j$ by the household of country $i$

$$
X_{i t}^{j}=\frac{C_{i t}^{j}-H_{i t}^{j}}{C_{i t}^{j}}, \quad i=1,2, \quad j=1,2 .
$$

When $C_{i t}^{j}=H_{i t}^{j}, X_{i t}^{j}=0$ : this is the worst possible state. By contrast, as $C_{i t}^{j}$ rises, the surplus consumption ratio converges on unity. We closely follow Campbell and Cochrane (1999) by assuming that the log of the surplus consumption ratios evolve as follows 


$$
x_{t}^{j}=(1-\phi) \bar{x}^{j}+\phi x_{t-1}^{j}+\lambda\left(x_{t-1}^{j}\right)\left(v_{t}^{j}\right), \quad j=1,2,
$$

where $\phi<1$, is the habit persistence parameter, $\bar{x}^{j}$ is the steady state value for the logarithm of the surplus consumption ratio for good $j$ and $v_{t}^{j}$ is the shock to consumption growth in country $j$. The function $\lambda\left(x_{t}^{j}\right)$ describes the sensitivity of the future log surplus consumption ratio to endowment innovations. It depends non-linearly on the current log surplus consumption ratio. The form of the sensitivity function $\lambda\left(x_{t}^{j}\right)$ is

$$
\begin{array}{rlrl}
\lambda\left(x_{t}^{j}\right) & =\frac{\sqrt{1-2\left(x_{t}^{j}-\bar{x}^{j}\right)}}{\bar{X}^{j}}-1 & \text { for } x_{t}^{j} \leq x_{\max }^{j} \\
& =0 & \text { for } x_{t}^{j}>x_{\max }^{j} \\
\text { where } x_{\max }^{j} & =\bar{x}^{j}+\frac{1-\left(\bar{X}^{j}\right)^{2}}{2} . & &
\end{array}
$$

$\bar{X}^{j}$ is the steady state value of the surplus consumption ratio for good $j$ and is defined as

$$
\bar{X}^{j}=\sigma_{v^{j}} \sqrt{\frac{\gamma}{1-\phi}} .
$$

We define $\sigma_{v^{j}}$ as the standard deviation of the innovation to the consumption of the $j^{\text {th }}$ good. There are a couple of advantages to specifying the habit along the lines of equations (6)-(8). Firstly, the habit is predetermined at the steady state. This means that it takes time for the consumption externality to affect an individual agents habit. The second advantage avoids a possible difficulty with the first. The habit is not predetermined outside of the steady state but if it were, a sufficiently low realization of consumption would mean that habit exceeded current consumption. The arguments of the utility functions in equation (4) become negative. Our habit specification prevents this by ensuring that the habit moves nonnegatively with consumption everywhere. These two features are illustrated in detail in Campbell and Cochrane (1999). Most importantly, for the problems that we are addressing, 
the form of the external habit in equations (6)-(8) guarantees that the intratemporal marginal rate of substitution in (1) and (2) is both volatile and persistent.

The rest of the model is as follows. The agent in the goods market faces the following cash-in-advance constraint

$$
M_{i t}^{j} \geq P_{t}^{j} C_{i t}^{j}, \quad i=1,2, \quad j=1,2,
$$

where $M_{i t}^{j}$ is the amount of money of country $j$ held by the household of country $i$ for transactions in the goods market at time t. At the end of period $t$ (or the beginning of period $\mathrm{t}+1$ ), the domestic households holding of domestic currency

$$
M_{1 t+1}^{1} \geq P_{t}^{1} C_{t}^{1}+B_{1 t}^{1}
$$

is made up of proceeds from the sale of the endowment and the redemption of nominal discount bonds, $B_{i t}^{j}$. The domestic household's holding of foreign currency is

$$
M_{1 t+1}^{2} \geq B_{1 t}^{2}
$$

Analogously the foreign households holding of foreign currency is

$$
M_{2 t+1}^{2} \geq P_{t}^{2} C_{t}^{2}+B_{2 t}^{2}
$$

and of domestic currency is

$$
M_{2 t+1}^{1} \geq B_{2 t}^{1}
$$

The only role for the government is to have a central bank that engages in open market operations. In each period the central bank of each country changes the money stock by issuing one-period discount bonds. The bonds are redeemed at the end of period $t$ (or the beginning of period $t+1$ ). Equilibrium in the goods market is given by

$$
C_{t}^{j}=C_{1 t}^{j}+C_{2 t}^{j}, \quad j=1,2 .
$$

Equilibrium in the money market given by:

$$
M_{t}^{j}=M_{1 t}^{j}+M_{2 t}^{j}, \quad j=1,2,
$$


Each household maximizes Eq. (4) subject ${ }^{9}$ to Eqs. (5)-(15). Like Lucas (1982) we assume that there is perfect international risk pooling in equilibrium. Recent work by Brandt, Cochrane and Santa-Clara (2001) suggests that international risk sharing is very high. With perfect risk sharing the equilibrium consumption of each good equals half of the current endowment i.e. $C_{j t}^{i}=0.5 Y_{t}^{i}$, where $Y_{t}^{i}, i=1,2$ is endowment of the $i^{\text {th }}$ country at time t. The solution is conventional and the expression for the real exchange rate can be found readily from equation (1) and the utility function (4)

$$
R_{t}=\frac{\left(C_{t}^{2} X_{t}^{2}\right)^{-\gamma}}{\left(C_{t}^{1} X_{t}^{1}\right)^{-\gamma}}
$$

Recalling that we use lowercase letters to indicate the log of a variable, we can write

$$
r_{t}=\gamma\left(y_{t}^{1}-y_{t}^{2}\right)+\gamma\left(x_{t}^{1}-x_{t}^{2}\right)
$$

and

$$
s_{t}=(\gamma-1)\left(y_{t}^{1}-y_{t}^{2}\right)+\gamma\left(x_{t}^{1}-x_{t}^{2}\right)+\left(m_{t}^{1}-m_{t}^{2}\right) .
$$

In the standard case where there are no habits in the utility function: the $x_{t}^{j}$ terms are not present. In Chari, Kehoe and McGrattan (2001) the log-linearized real and nominal exchange rates depend on both aggregate income and money differentials in a similar way to (17) and (18) and it is obvious why they need a large value for $\gamma$. The curvature parameter ${ }^{10}$ needs to be above unity so as to generate positive correlations between real and nominal exchange rates and needs to be large to generate the required volatility. We do not need this restriction because it is the presence of the log surplus consumption ratio differential in both (17) and (18) that secures this correlation in our model. In addition Chari, Kehoe and McGrattan (2001) need to assume price stickiness for at least four quarters in order to generate persistence in the real exchange rate. If households have Campbell and Cochrane (1999) habits in domestic and foreign goods neither large $\gamma$ nor price stickiness is required to 
generate persistent, volatile and highly correlated real and nominal exchange rates. The $x_{t}^{j}$ terms generate volatility, persistence and high correlation.

Since the classic paper by Meese and Rogoff (1983) economists have found it difficult to explain why the random walk exchange rate model outperforms many other models in short horizon forecasting. They calculated the root mean squared forecast error (RMSE) for the monetary model (RMSE $\left.E_{\bmod }\right)$ and for the random walk model $\left(\mathrm{RMSE}_{\mathrm{rw}}\right)$ and computed $\mathrm{RMSE}_{\text {mod }} / \mathrm{RMSE}_{\mathrm{rw}}$. The relative RMSE tends to be greater than unity at most forecast horizons. To investigate this we conduct two types of experiment. We follow Mark (1995) and Faust, Rogers and Wright (2001) and estimate the following exchange rate equation at forecast horizon $k$

$$
s_{t+k}-s_{t}=\alpha_{k}+\beta_{k} z_{t}+e_{t} \quad e_{t} \sim \operatorname{iid}\left(0, \sigma_{e}^{2}\right),
$$

where $z_{t}$ is the log deviation of the exchange rate from fundamentals predicted by the "monetary model" and is given by

$$
z_{t}=(\gamma-1)\left(y_{t}^{1}-y_{t}^{2}\right)+\left(m_{t}^{1}-m_{t}^{2}\right)-s_{t}
$$

In these studies point estimates of $\beta_{k}$ are positive and tend to increase with the horizon $k$. Mark (1995) and Faust, Rogers and Wright (2001) compute recursive out of sample forecasting exercises. They leave the last forty observations of a sample of size $\mathrm{T}$ for evaluation. They estimate (19) with T-40 observations and produce forecasts for horizons 1, 4, 8, 12 and 16 quarters. Then they add one observation to the end of the estimation sample and repeat the forecasting exercise. This results in $40 \mathrm{k}=1$ quarter forecasts, $37 \mathrm{k}=4$ quarter forecasts, $33 \mathrm{k}=8$ quarter forecasts, $29 \mathrm{k}=12$ quarter forecasts and $25 \mathrm{k}=16$ quarter forecasts. Using real time data Faust, Rogers and Wright (2001) show that the relative RMSE was greater than unity and increasing with the forecast horizon for three out the four US dollar exchange rates studied ${ }^{11}$. For ease of comparison, an example of their results is reproduced as Table 2. 
In the second experiment, we use our model to generate simulated values of money, income and the nominal exchange rate. We then estimate the following standard monetary model by using the fully modified techniques developed by Phillips and Hansen (1990).

$$
s_{t}=\alpha_{0}+\alpha_{1}\left(y_{t}^{1}-y_{t}^{2}\right)+\alpha_{2}\left(m_{t}^{1}-m_{t}^{2}\right)+e_{t} \quad e_{t} \sim \operatorname{iid}\left(0, \sigma_{e}^{2}\right) .
$$

We test for cointegration in repeated simulated samples. In addition, we test the restrictions implied by equation (18) using fully modified standard errors. Numerous writers have pointed out how difficult it is to obtain cointegration from equations such as (21) or to even obtain sensible estimates of its parameters. There is a good survey of such work included in Taylor (1995).

\section{The Data}

There have been many studies documenting properties of bilateral exchange rates between the United States and European countries (see for example Chari, Kehoe and McGrattan (2001). The series used in this paper are constructed from raw data for the United States and the 15 countries of the European Union. The data are collected by the Organisation for Economic Co-operation and Development (OECD) and the International Monetary Fund (IMF) and are available from Datastream. The data are quarterly and cover the floating period 1973:1 to 1998:4. The nominal exchange rates, $S_{t}$, defined as the dollar price of one unit of foreign exchange, are converted to real exchange rates, $R_{t}=S_{t} P_{t}^{2} / P_{t}^{1}$, using each country's consumer price index. In addition to presenting basic statistics on bilateral exchange rates vis-à-vis the United States we also calculate a trade-weighted European nominal exchange rate using the following formula

$$
I_{t}=I_{t-1} \prod_{j=1}^{n}\left(\frac{S_{j, t}}{S_{j, t-1}}\right)^{W_{j, t}},
$$


where $I_{t}$ is the nominal index and $W_{j, t}$ is the weight of currency $j$ at time $t$ in the total competitiveness index for the U.S. dollar. The base period (1973:1 in our data set) is assumed to take on the value equal to 100 . The weights are those employed by the Board of Governors of the Federal Reserve System in their trade-weighted exchange rate indices and are available from their website ${ }^{12}$. For a thorough discussion on the construction of these specific indices see Leahy (1998). In addition, Coughlin and Pollard (1996) present a detailed investigation of the issues involved in the construction of commonly used tradeweighted indices. We also calculate a trade-weighted European-United States real exchange rate using individual country consumer price indices and a trade-weighted European consumer price level.

We present some basic statistics for logged real and nominal exchange rates and the CPI ratio, all relative to the United States, in Table 1. The stylized facts for Hodrick-Prescott filtered data are very similar to those reported by Chari, Kehoe and McGrattan (2001) even though we consider more countries and over a longer time period. Real and nominal exchange rates are very volatile with standard deviations of around $8 \%$ and $\mathrm{AR}(1)$ coefficients of around 0.8. The two series are very highly correlated: the correlation coefficient exceeds $90 \%$ in every case. International price ratios are much less variable than either real or nominal exchange rates. Fourteen out of the fifteen countries display standard deviations in the range $1.24 \%$ to $2.75 \%$ and the EU average is at the lower end at $1.37 \%$. The AR(1) coefficient for the price ratio is also high but varies between .67 and .95.

\section{Calibration}

We assume that the log-level of endowment and money are exogenously given by a second order vector autoregression:

$$
W_{t}=\Phi_{0}+\Phi_{1} W_{t-1}+\Phi_{2} W_{t-2}+U_{t}, \quad U_{t} \sim M N(0, \Sigma)
$$


where $W_{t}^{\prime}=\left(c_{t}^{1}, c_{t}^{2}, m_{t}^{1}, m_{t}^{2}\right)$ and the vector of exogenous shocks is $U_{t}^{\prime}=\left(v_{t}^{1}, v_{t}^{2}, u_{t}^{1}, u_{t}^{2}\right)$. This specification will allow us to analyze a wide range of levels of persistence in both the level and growth rate of endowment and money. We present the baseline parameterization in Table 3 that we use in Section IV to simulate a "quarterly economy". The parameters of the exogenous endowment and money growth rate processes are taken from the literature. Campbell and Cochrane (1999) use U.S. real consumption expenditure on non-durables and services to proxy for endowments. They estimate the first-order autocorrelation coefficient to be zero and the standard deviation of shocks to consumption growth to be $0.56 \%$ per quarter. We use these parameters in our baseline. Christiano (1991) uses U.S. base money growth as his measure of money. Using data on seasonally adjusted U.S. adjusted monetary base from the Federal Reserve Bank of St. Louis’ database for the period 1973:1-1998:4 we estimated the first-order autocorrelation coefficient to be 0.35 and the standard error of the shock to money base growth to be $0.6 \%$ per quarter. We use these parameters in our baseline.

The elasticity of intertemporal substitution, $1 / \gamma$, and the AR(1) coefficient of the log of the surplus consumption ratio, $\phi$, have major effects in the habit persistence model. In the baseline parameterization we set the elasticity of intertemporal substitution equal to $10.00(\gamma=0.1)$. However, even with $\gamma=0.1$, it is worth remembering that the local curvature of the utility function at the steady state is $\frac{\gamma}{\bar{X}}=9.78$. The AR(1) coefficient of log surplus consumption is set equal to 0.97, a value used in Campbell and Cochrane (1999).

We perform sensitivity analysis and examine how the results change when we vary key parameters. Chari, Kehoe and McGrattan (2000) use total consumption as their measure of consumption. Using data on seasonally adjusted U.S. total consumption obtained from the Federal Reserve Bank of St. Louis’ database for the period 1973:1-1998:4, we estimated the first-order autocorrelation coefficient to be 0.1 and the standard error of the shock to 
consumption growth to be $0.86 \%$ per quarter. We use these parameters in two extra experiments to investigate the quantitative effect of increasing persistence or the size of the shock in consumption growth. Chari, Kehoe and McGrattan (2001) use U.S. data for M1 growth and estimate the first-order autocorrelation coefficient to be 0.68 . They do not report the standard deviation of the shock to money growth but state that they "choose the standard deviation of these shocks that will give the same volatility for output as in the U.S. data”. This implies a counterfactually high standard deviation of money growth of $2.3 \%$ per quarter. In their data set they report that it is $1.15 \%$. Using data on seasonally adjusted U.S. M1 obtained from the Federal Reserve Bank of St. Louis’ database for the period 1973:1-1998:4 we estimated the first-order autocorrelation coefficient to be 0.6 and the standard error of the shock to M1 growth to be $1.1 \%$ per quarter. We use these parameters in two further experiments to investigate the quantitative effect of increasing persistence or the size of the shock in money growth.

\section{The results}

We simulated the standard and habit models using Eqs. (6)-(8), (17)-(18)and (23). We replicate each experiment 1,000 times generating 644 observations for each series. The first 500 observations are discarded leaving a sample size of 144 . The last 40 observations are reserved for forecasting. This leaves a simulated sample size of 104 and is the typical sample size used in Section III. The simulated data are Hodrick-Prescott filtered.

\section{IV.I Volatile and persistent exchange rates}

The results from the baseline parameterizations for the moments of interest are contained in Table 4 where we present the mean of the simulated moment and its standard error (in 
parenthesis) for both the habit and standard models. We also report the benchmark economy results presented by Chari, Kehoe and McGrattan (2001) ${ }^{13}$.

It is obvious that the volatility of real and nominal exchange rates in the standard model is very low and that their correlation is counterfactually negative. This simply confirms what has already been noted elsewhere in the literature. By contrast, the new habit model comes satisfyingly close to describing the data. Both real and nominal exchange rates have standard deviations close to the $8 \%$ that we reported for the data in Table 1 . The AR(1) coefficients at 0.65 and 0.62 respectively are somewhat lower than the value of 0.8 that we observe in the data but still exhibit high levels of persistence. The most pleasing result of all is the high correlation between real and nominal exchange rates: at $91 \%$ it is comfortably within the range reported in Table 1. Finally the standard deviation and AR(1) coefficient of the price ratio are $1.74 \%$ and 0.78 and are in the range we see in the data.

Two questions immediately come to mind. How does our model compare to Chari, Kehoe and McGrattan (2001)? It is not part of our agenda to suggest that sticky price models such as theirs do not explain the data. We could be argumentative and point out that their model generates excess volatility in the price ratio (see the first entry of the last line in Table 4). However the overall impression conveyed by Table 4 is that the habit model produces simulated moments that are very similar to those produced by Chari, Kehoe and McGrattan (2001). Both are broadly successful in explaining the stylized facts. The final question relates to the sensitivity of our results to our parameter assumptions. Table 4a contains the results of a number of experiments that were flagged in section 3. The overall impression is that the results do not change substantially if the parameters of the exogenous forcing process are varied within plausible ranges.

We present a few results not addressed in Chari, Kehoe and McGrattan (2001). These results are related to the Meese-Rogoff or the 'exchange-rate disconnect' puzzle. Using the 
data derived from simulating the habit model we estimate Eq. (21) using the fully modified procedure due to Phillips and Hansen (1990). Even though the nominal exchange rate is cointegrated with endowment and money differentials, by construction, the ADF unit root test on the residuals from Eq. (21) is rejected $35.1 \%$ of the time. We also perform a Wald test of the null hypothesis that $\alpha_{1}=\gamma-1$ and $\alpha_{2}=1$. This is rejected $73.5 \%$ of the time. These results are summarized in Table 5 . Table 5 also shows that they are not simply due to the assumptions about the forcing process.

These results would concur with the empirical finding (See, for example, Frankel and Rose, 1995) that equations like (21) fit very poorly, even when estimated using techniques that recognize the non-stationary nature of the data. The explanation is obvious. Though Eq. (21) is correctly specified as a cointegrating regression, the true model in equation Eq. (18) contains a near integrated process that gives the non-stationary inference low power in conventional sample sizes. The near-integrated process is, of course, the surplus consumption ratio differential.

Finally we conduct a forecasting exercise. The simulated data on endowment and money differentials in the forecast period are used with the estimated Eq. (19) to construct forecasts for the nominal exchange rate for horizons up to 16 quarters. These forecasts are then compared to nominal exchange rates generated by the habit model in Eq.(18). We report the relative RMSE for 1, 4, 8, 12 and 16 quarter forecast horizons in Table 6. Like the results found by Faust, Rogers and Wright (2001), for three out of four currency pairs, the relative RMSE is always greater than unity and does not diminish at longer horizons. In fact, even the magnitude of the simulated relative RMSE's is remarkably similar to those found by Faust, Rogers and Wright (See Table 2). The mean of the estimates of $\beta_{k}$ in Eq. (19) are positive and tend to increase with the forecast horizon $k$. This pattern is similar to those found by Faust, Rogers and Wright (2001) (see their Figure 3). Table 6a displays a sensitivity 
analysis and shows that the results of Table 6 are not peculiar to the selected values for the exogenous forcing processes.

The reason why linear exchange forecasting models such as Eq. (19) are so poor is that the differential in the log surplus consumption ratio is omitted. Though this series is stationary it is both highly autoregressive and volatile. It is non-linearly related to fundamentals: though the model, of course, has the properties of long-run mean reversion and long-horizon predictability by construction, the short-run deviations of the nominal exchange rate from fundamentals are very volatile. No linear forecasting equation such as (19) or (21) is capable of capturing this subtlety. Our habit model lends support to the work of Taylor and Peel (2000), Clarida, Sarno, Taylor, and Valente (2001), Kilian and Taylor (2001) and Taylor (2001) all of which emphasize the importance of non-linearities in nominal exchange rate and purchasing power parity modelling.

\section{Conclusions}

The point of this paper is simple. Using a flexible price model with a simple twist, it is perfectly possible to explain many of the puzzles associated with purchasing power parity and nominal exchange rates under floating exchange rates. The volatility and persistence of both real and nominal exchange rates along with their correlation can be mimicked so long as preferences are subject to an aggregate consumption externality.

The model, proposed here, still has limitations. It only describes an exchange economy. Ljungqvist and Uhlig (2000) have pointed out that there are problems in expanding the Campbell and Cochrane (1999) framework to a production economy. 'Consumption bunching' rather than consumption smoothing becomes welfare optimal. However, this only arises if the habit is internalised: our habit is strictly an externality. It would be useful to extend our model to include production in order examine related puzzles that only arise in 
that context. These include the high correlation between real exchange rates and international output ratios, (See Finn 1999). Finally the model, as it stands, cannot explain why real exchange rates are more volatile under floating than fixed exchange rates. Notwithstanding these reservations, this paper demonstrates that the despair of Flood and Rose (1999) is premature and the contrivance of sticky prices may not be necessary. 


\section{References}

Abel, Andrew. “Asset Prices Under Habit Formation and Catching Up with the Joneses.” A.E.R., Papers and Proceedings 80 (May 1990): 38-42.

Bergin, Paul R., and Feenstra, Robert C. "Pricing-to-Market, Staggered Contracts and Real Exchange Rate Persistence.” J. Internat. Econ. 54, (August 2001): 333-359.

Brandt, Michael W., Cochrane, John H. and Santa-Clara, Pedro "International Risk Sharing is Better Than You Think (or Exchange Rates Are Much Too Smooth).” Working Paper no. 8404. Cambridge, Mass.: NBER, (July 2001).

Campbell, John Y., and Cochrane, John H. “By Force Of Habit: a Consumption-Based Explanation of Aggregate Stock Market Behaviour.” J.P.E. 107, (April 1999): 205-251

Chari, V.V., Kehoe, Patrick J. and McGrattan, Ellen R. “Can Sticky Price Models Generate Volatile and Persistent Real Exchange Rates?” Federal Reserve Bank of Minneapolis Staff Report 277, (December 2001).

Christiano, Laurence J. "Modelling the Liquidity Effect of a Money Shock.” Federal Reserve Bank of Minneapolis Quarterly Review (Winter 1991): 3-34.

Clarida, Richard H., Sarno, Lucio, Taylor, Mark P. and Valente, Giorgio. “The Out-of-Sample Success of Term Structure Models as Exchange Rate Predictors: A Step Beyond”, Manuscript, (August 2001).

Coughlin, Cletus C. and Pollard, Patricia S. “A Question of Measurement: is the Dollar Rising or Falling?” Federal Reserve Bank of St. Louis Review (July/August 1996): 3-18.

Duesenberry, J. S., Income, Saving and the Theory of Consumer Behaviour. Cambridge, Mass.: Harvard Univ. Press, 1949.

Engel, Charles, “On the foreign exchange risk premium in a general equilibrium model”, J. of Internat. Econ. 32, (1992,): 305-319. 
Engel, Charles, “Accounting for Real Exchange Rate Changes”, J.P.E. 107, (June 1999): 507-538.

Finn, Mary G., “An Equilibrium Theory of Nominal and Real Exchange Rate Comovement” J. Monetary Econ. 44, (December 1999): 453-475.

Flood, Robert P. and Rose, Andrew K., “Understanding Exchange Rate Volatility without the Contrivance of Macroeconomics.” Economic Journal 109, (1999): 660-672.

Frankel Jeffrey and Rose, Andrew K., “Empirical Research on Nominal Exchange Rates”, in Handbook of International Economics vol. 3, Gene Grossman and Kenneth Rogoff (eds.), (Amsterdam: Elsevier Publishers B.V., 1995): 1689-1729.

Hau, Harald, "Competitive Entry and Endogenous Risk in the Foreign Exchange Market.” Review of Financial Studies 11, (Winter 1998): 757-788.

Hodrick, Robert J. “The Empirical Evidence on the Efficiency of Forward and Futures Foreign Exchange Markets.” Switzerland: Harwood Academic Publishers, 1987.

Faust, Jon, Rogers, John and Wright, Jonathan H. "Exchange Rate Forecasting: The Errors We’ve Really Made.” Manuscript (August 2001).

Jeanne, Olivier. and Rose Andrew K., “Noise trading and exchange rate regimes”, Quarterly Journal of Economics, forthcoming 2002.

Kilian, Lutz and Taylor, Mark P. "Why is it so Difficult to Beat the Random Walk Forecast of Exchange Rates.” Manuscript (April 2001).

Lane, Philip R. “The New Open Economy Macroeconomics: a Survey.” J. of Internat. Econ. 54, (August 2001): 235-266.

Leahy, Michael P. "New Summary Measures of the Foreign Exchange Value of the Dollar” Federal Reserve Bulletin, (October 1998): 811-818.

Ljungqvist, Lars and Uhlig, Harald, “Tax Policy and Aggregate Demand Management under Catching up with the Joneses.” A.E.R. 90, (June 2000): 356-366. 
Lucas, Robert E. “Interest Rates and Currency Prices in a Two-country World.” J. Monetary Econ. 10, (November 1982): 335-360.

Mark, Nelson, “Exchange rates and Fluctuations: Evidence on Long-Horizon Predictability.” A.E.R. 85, (March 1995): 201-218.

Mendoza, Enrique G. “The Terms of Trade, The Real Exchange Rate and Economic Fluctuations.” International Economic Review 36, (February 1995): 101-137. Meese, Richard A. and Rogoff, Kenneth. "Empirical Exchange Rate Models of the Seventies, Do They Fit Out of Sample?.” J. of Internat. Econ. 14, (February 1983): 3-24.

Moore, Michael J. and Roche, Maurice J. "Less of a Puzzle: a New Look at the Forward Forex Market.” J. of Internat. Econ. forthcoming (2002).

Obstfeld, Maurice and Rogoff, Kenneth. “New Directions For Stochastic Open Economy Models.” J. of Internat. Econ. 50, (February 2000): 117-153.

Obstfeld, Maurice and Rogoff, Kenneth. “The Six Major Puzzles in International Macroeconomics: Is there a Common Cause?” NBER Macroeconomics Annual, 15, Cambridge Mass: MIT Press, 2001.

Osler, Carol, "Short-Term Speculators and the Puzzling Behaviour of Exchange Rates.” Journal of International Economics 45, (June 1998): 37-58.

Oswald, Andrew J. and Clarke, Andrew E. “Satisfaction and Comparison Income.” J. Public Econ. 61, (September 1996): 359-381.

Oswald, Andrew J. “Happiness and Economics.” Economic Journal 107, (November 1997): $1815-1831$.

Philips, Peter C.B. and Hansen, Bruce E. "Statistical Inference in Instrumental Variables Regression with I(1) Processes.” Review of Economic Studies 57, (1990): 99-125. 
Taylor, Alan M. "Potential Pitfalls for the purchasing Power Parity Puzzle? Sampling and Specification Biases in Mean Reversion Tests of the Law of One Price.” Econometrica, 69, (2001): 473-498.

Taylor, Mark P. “The Economics of Exchange Rates.” Journal of Economic Literature, 33, (1995): 13-47.

Taylor, Mark P. and Peel, David A. "Nonlinear Adjustment, Long Run Equilibrium and Exchange Rate Fundamentals.” Journal of International Money and Finance, 19, (2000): 3353. 
TABLE 1

Properties of exchange rates and consumer price indices in the data

\begin{tabular}{|c|c|c|c|c|c|c|c|}
\hline & \multicolumn{3}{|c|}{ Standard deviations } & \multicolumn{3}{|c|}{ AR(1) coefficients } & \multirow{4}{*}{$\begin{array}{c}\text { Cross- } \\
\text { correlations } \\
\text { Real and } \\
\text { Nominal } \\
\text { Exchange } \\
\text { Rates }\end{array}$} \\
\hline & \multirow{2}{*}{\multicolumn{4}{|c|}{$\begin{array}{l}\text { Nominal Real } \\
\text { Exchange Exchange }\end{array}$}} & \multirow{2}{*}{\multicolumn{2}{|c|}{$\begin{array}{l}\text { Nominal Real } \\
\text { Exchange Exchange }\end{array}$}} & \\
\hline & & & & & & & \\
\hline & Price Ratio & Rate & Rate & Price Ratio & Rate & Rate & \\
\hline Austria & 1.61 & 8.60 & 8.44 & 0.89 & 0.77 & 0.76 & 0.98 \\
\hline Belgium & 2.13 & 9.47 & 8.95 & 0.95 & 0.81 & 0.78 & 0.97 \\
\hline Denmark & 1.24 & 8.50 & 8.45 & 0.69 & 0.78 & 0.77 & 0.99 \\
\hline Finland & 1.90 & 8.49 & 7.85 & 0.89 & 0.84 & 0.83 & 0.98 \\
\hline France & 1.24 & 8.96 & 8.42 & 0.91 & 0.81 & 0.78 & 0.99 \\
\hline Germany & 1.50 & 8.84 & 8.60 & 0.90 & 0.78 & 0.76 & 0.99 \\
\hline Greece & 2.75 & 7.08 & 7.01 & 0.67 & 0.75 & 0.70 & 0.94 \\
\hline Ireland & 2.30 & 8.74 & 7.68 & 0.86 & 0.81 & 0.73 & 0.97 \\
\hline Italy & 1.67 & 8.91 & 8.22 & 0.85 & 0.81 & 0.78 & 0.98 \\
\hline Luxembourg & 2.32 & 9.47 & 8.77 & 0.95 & 0.81 & 0.77 & 0.97 \\
\hline Netherlands & 1.70 & 8.80 & 8.61 & 0.90 & 0.78 & 0.76 & 0.98 \\
\hline Portugal & 3.86 & 8.63 & 7.22 & 0.82 & 0.81 & 0.68 & 0.90 \\
\hline Spain & 2.30 & 9.03 & 8.69 & 0.89 & 0.84 & 0.82 & 0.97 \\
\hline Sweden & 1.76 & 8.64 & 8.16 & 0.80 & 0.80 & 0.78 & 0.98 \\
\hline United Kingdom & 2.54 & 8.45 & 8.06 & 0.85 & 0.81 & 0.78 & 0.98 \\
\hline EU & 1.37 & 8.19 & 7.65 & 0.91 & 0.81 & 0.78 & 0.99 \\
\hline
\end{tabular}

Note to the table: the statistics are based on logged and H-P filtered quarterly data for the period 1973:1-1998:4. The statistics for the European Union are trade-weighted aggregates of all countries in the table with the exception of Denmark and Greece. 
TABLE 2

Relative RMSE of the monetary model in out-of-sample forecasting

\begin{tabular}{lccccc}
\hline Forecast Horizon $k$ & 1 & 4 & 8 & 12 & 16 \\
Canada & 0.99 & 0.81 & 0.63 & 0.65 & 0.55 \\
Germany & 1.01 & 1.10 & 1.87 & 2.52 & 2.90 \\
Japan & 1.00 & 0.98 & 1.01 & 1.17 & 1.40 \\
Switzerland & 1.00 & 0.93 & 1.02 & 1.01 & 1.13 \\
\hline
\end{tabular}

Note to the table: These results are taken from Table 1 in Faust, Rogers and Wright (2001). The entries in the table show the ratio of the out-of-sample RMSE from the monetary model to that of the driftless random walk model using real-time data. The exchange rates are versus the U.S. dollar. 
TABLE 3

Baseline parameterization

\begin{tabular}{lcc}
\hline \hline & Consumption growth & Money growth \\
\cline { 2 - 3 } AR(1) coefficient & 0.00 & 0.35 \\
Standard deviation of shock & $0.56 \%$ & $0.60 \%$ \\
& & \\
Curvature of the utility function $\gamma$ & & 0.10 \\
Persistence of the log surplus-consumption ratio $\phi$ & 0.97 \\
\hline
\end{tabular}


TABLE 4

Properties of exchange rates and consumer price indices in the simulated models

\begin{tabular}{|c|c|c|c|c|c|c|c|}
\hline & \multicolumn{3}{|c|}{ Standard Deviations } & \multicolumn{3}{|c|}{ AR(1) coefficients } & \multirow{2}{*}{$\begin{array}{c}\text { Cross- } \\
\text { correlations } \\
\text { Real and } \\
\text { Nominal } \\
\text { Exchange } \\
\text { Rates }\end{array}$} \\
\hline & $\begin{array}{l}\text { Price } \\
\text { Ratio }\end{array}$ & $\begin{array}{l}\text { Nominal } \\
\text { Exchange } \\
\text { Rate }\end{array}$ & $\begin{array}{c}\text { Real } \\
\text { Exchange } \\
\text { Rate }\end{array}$ & $\begin{array}{l}\text { Price } \\
\text { Ratio }\end{array}$ & $\begin{array}{l}\text { Nominal } \\
\text { Exchange } \\
\text { Rate }\end{array}$ & $\begin{array}{c}\text { Real } \\
\text { Exchange } \\
\text { Rate }\end{array}$ & \\
\hline$\overline{\text { Data }}$ & 1.37 & 8.19 & 7.65 & 0.91 & 0.81 & 0.78 & 0.99 \\
\hline Habit & $\begin{array}{c}1.74 \\
(0.00)\end{array}$ & $\begin{array}{l}7.74 \\
(0.002)\end{array}$ & $\begin{array}{c}7.88 \\
(0.002)\end{array}$ & $\begin{array}{c}0.78 \\
(0.02)\end{array}$ & $\begin{array}{c}0.65 \\
(0.004)\end{array}$ & $\begin{array}{l}0.62 \\
(0.004)\end{array}$ & $\begin{array}{c}0.91 \\
(0.003)\end{array}$ \\
\hline Standard & & $\begin{array}{l}1.69 \\
(0.000)\end{array}$ & $\begin{array}{c}0.001 \\
(0.000)\end{array}$ & & $\begin{array}{c}0.78 \\
(0.002)\end{array}$ & $\begin{array}{c}0.69 \\
(0.002)\end{array}$ & $\begin{array}{l}-0.51 \\
(0.005)\end{array}$ \\
\hline CKM & $\begin{array}{c}5.46 \\
(0.75)\end{array}$ & $\begin{array}{c}7.86 \\
(0.80)\end{array}$ & $\begin{array}{c}7.77 \\
(0.72)\end{array}$ & $\begin{array}{c}0.93 \\
(0.02)\end{array}$ & $\begin{array}{c}0.69 \\
(0.08)\end{array}$ & $\begin{array}{c}0.62 \\
(0.08)\end{array}$ & $\begin{array}{c}0.76 \\
(0.06)\end{array}$ \\
\hline
\end{tabular}

Note to the table: 'Data' refers to the USA/EU stylized facts in the last row of Table 1. Each series is logged and detrended using the Hodrick-Prescott filter. The means of each detrended series in the habit and standard models based on 1000 simulations are reported with the associated standard error in parenthesis. The means of each series in the Chari, Kehoe and McGrattan (2001) (CKM) benchmark economy model based on 100 simulations are reported with the associated standard error in parenthesis in the last row. 
TABLE 4a

Sensitivity analysis

Properties of exchange rates and consumer price indices in the simulated habit model

\begin{tabular}{|c|c|c|c|c|c|c|c|}
\hline & \multicolumn{3}{|c|}{ Standard Deviations } & \multicolumn{3}{|c|}{ AR(1) coefficients } & \multirow{2}{*}{$\begin{array}{c}\text { Cross- } \\
\text { correlations } \\
\text { Real and } \\
\text { Nominal } \\
\text { Exchange } \\
\text { Rates }\end{array}$} \\
\hline & Price Ratio & $\begin{array}{l}\text { Nominal } \\
\text { Exchange } \\
\text { Rate }\end{array}$ & $\begin{array}{c}\text { Real } \\
\text { Exchange } \\
\text { Rate }\end{array}$ & Price Ratio & $\begin{array}{c}\text { Nominal } \\
\text { Exchange } \\
\text { Rate }\end{array}$ & $\begin{array}{c}\text { Real } \\
\text { Exchange } \\
\text { Rate }\end{array}$ & \\
\hline$\overline{\text { Data }}$ & 1.37 & 8.19 & 7.65 & 0.91 & 0.81 & 0.78 & 0.99 \\
\hline Baseline Parametrization & 1.74 & 7.74 & 7.88 & 0.78 & 0.65 & 0.62 & 0.91 \\
\hline Raise S.D. of the consumption shock to $0.86 \%$ & 2.09 & 7.78 & 8.01 & 0.75 & 0.66 & 0.62 & 0.88 \\
\hline Raise S.D. of the money shock to $1.10 \%$ & 2.82 & 8.21 & 7.88 & 0.80 & 0.69 & 0.62 & 0.83 \\
\hline Raise AR(1) coefficient of consumption to 0.10 & 1.79 & 7.77 & 7.88 & 0.79 & 0.65 & 0.62 & 0.91 \\
\hline Raise AR(1) coefficient of money to 0.60 & 2.22 & 7.93 & 7.88 & 0.85 & 0.68 & 0.62 & 0.87 \\
\hline Raise S.D. of the money shock to $1.10 \%$ and & & & & & & & \\
\hline Raise AR(1) coefficient of money to 0.60 & 3.77 & 8.72 & 7.88 & 0.87 & 0.73 & 0.62 & 0.76 \\
\hline
\end{tabular}

Note to the table: The data refer to the USA/EU stylized facts in the last row of Table 1. Each series is logged and detrended using the HodrickPrescott filter. The means of each detrended series based on 1000 simulations are reported. S.D stands for standard deviation. The associated standard errors are available upon request. 
TABLE 5

Tests based on Eq. $(21)^{\mathrm{a}}$ : Percentage number of rejections ${ }^{\mathrm{b}}$

Residual

Wald test ${ }^{\mathrm{c}} \quad$ ADF test

Baseline Parametrization

$73.5 \%$

$35.1 \%$

Raise S.D. of the consumption shock to $0.86 \%$

$72.9 \%$

$32.4 \%$

Raise S.D. of the money shock to $1.10 \%$

$73.5 \%$

$35.1 \%$

Raise AR(1) coefficient of consumption to 0.10

$72.5 \%$

$35.3 \%$

Raise AR(1) coefficient of money to 0.60

$73.5 \%$

$34.8 \%$

Raise S.D. of the money shock to $1.10 \%$ and

Raise AR(1) coefficient of money to 0.60

$73.5 \%$

$34.8 \%$

Note to the table: The means of each series in the habit model based on 1000 simulations are reported. S.D stands for standard deviation. The associated standard errors are available upon request.

${ }^{\mathrm{a}}$ The equation was estimated using the fully modified techniques developed by Phillips and Hansen (1990).

${ }^{\mathrm{b}}$ The percentage number of rejections were calculated using a 5\% level of significance.

${ }^{\mathrm{c}}$ The Wald test is for the $\mathrm{H}_{0}: \alpha_{1}=\gamma-1$ and $\alpha_{2}=1$. 
TABLE 6

Out of sample forecasting evaluation

\begin{tabular}{lccccc}
\hline \hline Forecast Horizon $k$ & 1 & 4 & 8 & 12 & 16 \\
& 0.16 & 0.47 & 0.69 & 0.81 & 0.88 \\
$\beta_{k}$ & $(0.003)$ & $(0.007)$ & $(0.009)$ & $(0.010)$ & $(0.011)$ \\
& 1.02 & 1.04 & 1.08 & 1.14 & 1.20 \\
Relative RMSE & $(0.003)$ & $(0.009)$ & $(0.015)$ & $(0.022)$ & $(0.032)$ \\
\hline
\end{tabular}

Note to the table: The nominal exchange rate is generated using the log-linearized first order condition of the habit model. The entries in the table show the ratio of the out-of-sample RMSE from the monetary model to that of the driftless random walk model. The means of both the $\beta_{k}$ and the relative RMSE are estimated using the Faust, Rogers and Wright (2001) methodology and are based on 1000 simulations. The associated standard errors are in parenthesis.

\section{TABLE 6a}

Sensitivity analysis

Out of sample forecasting evaluation

\begin{tabular}{|c|c|c|c|c|c|}
\hline \multicolumn{6}{|c|}{ Estimates of $\beta_{k}$} \\
\hline Forecast Horizon & 1 & 4 & 8 & 12 & 16 \\
\hline Baseline Parametrization & 0.16 & 0.47 & 0.69 & 0.81 & 0.88 \\
\hline Raise S.D. of the consumption shock to $0.86 \%$ & 0.15 & 0.45 & 0.66 & 0.78 & 0.85 \\
\hline Raise S.D. of the money shock to $1.10 \%$ & 0.16 & 0.47 & 0.69 & 0.81 & 0.88 \\
\hline Raise AR(1) coefficient of consumption to 0.10 & 0.16 & 0.47 & 0.69 & 0.81 & 0.88 \\
\hline $\begin{array}{l}\text { Raise AR(1) coefficient of money to } 0.60 \\
\text { Raise S.D. of the money shock to } 1.10 \% \text { and }\end{array}$ & 0.16 & 0.47 & 0.69 & 0.81 & 0.88 \\
\hline Raise AR(1) coefficient of money to 0.60 & 0.16 & 0.47 & 0.69 & 0.81 & 0.88 \\
\hline
\end{tabular}

Relative RMSE

Forecast Horizon

Baseline Parametrization

Raise S.D. of the consumption shock to $0.86 \%$

Raise S.D. of the money shock to $1.10 \%$

Raise AR(1) coefficient of consumption to 0.10

Raise AR(1) coefficient of money to 0.60

Raise S.D. of the money shock to $1.10 \%$ and

Raise AR(1) coefficient of money to 0.60

$\begin{array}{ccccc}1 & 4 & 8 & 12 & 16 \\ 1.02 & 1.04 & 1.08 & 1.14 & 1.21 \\ 1.02 & 1.05 & 1.11 & 1.16 & 1.23 \\ 1.01 & 1.04 & 1.07 & 1.12 & 1.18 \\ 1.01 & 1.04 & 1.08 & 1.14 & 1.21 \\ 1.01 & 1.04 & 1.08 & 1.13 & 1.19\end{array}$

$\begin{array}{lllll}1.01 & 1.04 & 1.08 & 1.13 & 1.18\end{array}$

Note to the table: The nominal exchange rate is generated using the log-linearized first order condition of the habit model. The entries in the table show the ratio of the out-of-sample RMSE from the monetary model to that of the driftless random walk model. The means of both the $\beta_{k}$ and the relative RMSE are estimated using the Faust, Rogers and Wright (2001) methodology and are based on 1000 simulations. S.D stands for standard deviation. The associated standard errors are available upon request. 
${ }^{1}$ For example, Lucas (1982) with an addilog utility function in home and foreign goods.

${ }^{2}$ Alternatively, the covariances between money and income or home and foreign variables have to assume values not observed in the data.

${ }^{3}$ Related contributions include Hau (1998), Osler (1998) and Jeanne and Rose (2002)

${ }^{4}$ This is related to the Purchasing-Power Parity Puzzle. See Obstfeld and Rogoff (2001)

${ }^{5}$ This model could be labelled under the heading 'New Classical Open Economy

Macroeconomics' with apologies to Philip Lane.

${ }^{6}$ Strictly speaking, this is the terms of trade and the real exchange rate is the relative price of non-traded to traded goods. In this respect, we are following Finn (1999) and Bergin and Feenstra (2001). Mendoza (1995) compares the stylised facts of real exchange rates to those of the terms of trade. For example, the former is somewhat more volatile than the latter. Obstfeld and Rogoff (2000) also show that the correlation between nominal exchange rates and the terms of trade is weaker than that which typically characterises the comovement of nominal and real exchange rates. Nevertheless, all of the same qualitative stylised facts apply to both measures.

${ }^{7}$ The superscript denotes country of origin and the subscript denotes country of use. Uppercase letters denote variables in levels; lowercase letters denote variables in log levels, including growth and interest rates. Greek letters without time subscripts denote parameters. Bars over variables denote steady states.

${ }^{8}$ One of the main differences between our specification and that of Campbell and Cochrane (1999) is that we have two goods in the model. An alternative strategy would be to specify a single habit in a basket of home and foreign goods. We explored this possibility but it appears to be intractable. We could also have introduced a non-traded good in each country (with separate habits). This is tractable but the additional complexity is hard to justify in view of the evidence that very little of the volatility of real exchange rates can be attributed to the relative variability of non-traded and traded goods prices (see Engel, 1999).

${ }^{9}$ Recall that the habit is external. This idea is implemented by treating the surplus consumption ratio as exogenous in the optimisation problem.

${ }^{10}$ Defining risk aversion in a multi-good model is not trivial (see Engel, 1992 and Moore, 1997). An intertemporal model has as many goods as time periods. In addition, our model has two goods in each time period. We evade this problem by only considering its value at the steady state. The local curvature of the utility function with respect to good $j$ is

$$
=-C_{i t}^{j} \frac{\delta^{2} U / \delta\left(C_{i t}^{j}\right)^{2}}{\delta U / \delta C_{i t}^{j}}=\frac{\gamma}{\bar{X}_{i t}^{j}}=\frac{\gamma}{\bar{X}_{t}^{j}} \frac{\sqrt{\gamma(1-\phi)}}{\sigma_{c^{j}}} \quad i=1,2, \quad j=1,2,
$$

Campbell and Cochrane (1999) show that this expression is positively related to the coefficient of relative risk aversion for the one good case.

${ }^{11}$ Famously, Mark (1995) finds that as the forecast horizon increases, the Meese-Rogoff problem declines in severity and that the monetary model beats the random walk model. Faust, Rogers and Wright challenge this result in the following terms: "Had Mark (1995) constructed his dataset at almost any other time than early 1992, he would have found much less evidence of predictability. There is only a 2-year window around Mark's vintage in which the monetary model beats the random walk for both the DM and yen. That results like this arise from time to time is perhaps not surprising in an area where many researchers independently fit many models to each successive vintage. Only significant results are published. This sort of process seems likely to raise familiar data-mining problems" 12 The Fed does not report weights for Denmark and Greece. Luxembourg is included in the Belgian weights. Thus the EU aggregate is based on 12 countries

${ }^{13}$ Their Table 5 